\title{
Research Expeditions Performed by Marine Hydrophysical Institute in the Sivash Bay Waters in Spring and Autumn, 2018
}

\author{
E. E. Sovga, E. S. Eremina*, A. A. Latushkin \\ Marine Hydrophysical Institute of RAS, Sevastopol, Russian Federation \\ *shchurova88@gmail.com
}

\begin{abstract}
Purpose. The results of the expeditionary studies performed by Marine Hydrophysical Institute in the Sivash Bay waters in spring and autumn, 2018 are considered in the paper. Its aim is to continue comprehensive investigation of the bay after the North Crimean channel was closed in 2014, and to evaluate dynamics of salinity, dissolved organic and total suspended matters in its waters affected by the changed anthropogenic and natural-climatic factors. Relevance of the studies carried out in the bay water area is conditioned by urgent necessity in developing and implementing a modern system of environmental monitoring of the bay.

Methods and Results. The data obtained during two expeditions in spring and autumn, 2018 in the Sivash Bay waters including the present borders of the Eastern Sivash wetland are analyzed. At 13 stations, water salinity was determined by the refractometric and pycnometric methods, while the dissolved organic matter and the total suspended matter - by "Kondor" biophysical complex.

Conclusions. It is concluded that due to the fact that the North Crimean channel was closed in 2014, salinity of the Sivash Bay water continues to change and its ecosystem is being rebuilt. The observed salinity increase is not the same in different parts of the bay. The highest salinity values were observed in the Southern Sivash and amounted 92-93\%, whereas at the same stations in 2016, this value constituted 55-60\%. During the autumn survey, assessment of seasonal dynamics of the total suspended matter and the dissolved organic matter contents yielded high values of concentrations of these two parameters in the bay. In spring when the dissolved organic matter distribution is more monotonous, the slightly increased total suspended matter content was observed at the stations in the Southern Sivash.
\end{abstract}

Keywords: Sivash Bay, Eastern and Southern Sivash, Sea of Azov, seasonal salinity dynamics, total suspended matter, dissolved organic matter.

Acknowledgements: the work was carried out within the framework of the state task on the themes No. 0827-2019-0004 "Complex interdisciplinary investigations of the oceanologic processes conditioning functioning and evolution of the Black and Azov seas' coastal zones" and No. 0827-2019-0002 "Development of the methods of operational oceanology based on the interdisciplinary studies of the marine environment formation and evolution processes, and mathematical modeling using the data of remote and direct measurements".

For citation: Sovga, E.E., Eremina, E.S. and Latushkin, A.A., 2020. Research Expeditions Performed by Marine Hydrophysical Institute in the Sivash Bay Waters in Spring and Autumn, 2018. Physical Oceanography, [e-journal] 27(2), pp. 161-170. doi:10.22449/1573-160X-2020-2-161-170

DOI: $10.22449 / 1573-160 \mathrm{X}-2020-2-161-170$

(C) E. E. Sovga, E. S. Eremina, A. A. Latushkin, 2020

(C) Physical Oceanography, 2020

\section{Introduction}

The task of the expeditionary work in 2018 is to continue a comprehensive study of the Sivash Bay in accordance with the work plans of Marine Hydrophysical Institute (MHI) of the Russian Academy of Sciences to determine the dynamics of water salinity, total suspended (TSM) and dissolved organic (DOM) matters under conditions of altered anthropogenic (closure of the North Crimean Canal, reduction of the rise cultivation area) and natural and climatic 
factors in order to implement the jointly created by the Marine Hydrophysical Institute and Sevastopol Branch of State Oceanographic Institute (SBGOIN) a system of environmental monitoring of the bay and the development of practical proposals for creating the concept of environmental management in new conditions.

Eastern and Southern Sivash are the largest in area $\left(1650 \mathrm{~km}^{2}\right.$, or more than $60 \%$ of the Sivash Bay total area) and deeper (depths of up to $1 \mathrm{~m}$ occupy $41 \%$ of the area) water areas of the bay. Eastern Sivash was most affected by freshwater discharges. Most of the salina has been used for many years as a reservoir for waste water from rice fields. Under effect of the Dnieper spill and drainage waters some sections of the Eastern Sivash freshened up to $23 \%$. An increase in fresh water component in the Sivash water balance [1] created new environmental conditions with a change in the biological diversity and productivity of the basin [2]. The effect of the North Crimean Canal on the Sivash Bay is described in [3-5].

In 2014, when Crimea entered the socio-legal field of the Russian Federation, the North Crimean Canal was blocked. Respectively, the fresh water supply to the Sivash was sharply reduced, a new period of ecosystem transformation began and it continues to this day.

In 2014, part of the stations located in the north of the Arabat Spit became unavailable; in addition, it was impossible to carry out the works in the border zone without special permits, which limited the conduction of field studies. For the works in 2014-2016 the following points were selected: the Rogachinsky, Knyazhevich and Balganovsky bays as well as the area northwards of the Shakalinsky narrowing, and in 2016 - also the water area of the Southern Sivash. The results of these expeditionary studies are presented in [6, 7], which analyzed the dynamics of water salinity in the Eastern and Southern Sivash, determined its values during the functioning of the North Crimean Canal (2013) and from the moment of its blocking. The data presented in these works showed that the blocking of the North Crimean Canal in 2014 contributed to a significant change in salinity mainly in Eastern Sivash, which manifested itself unequally in its various stretches. These data confirmed the need for further research, the results of which will allow scientifically substantiating possible changes in the concept of environmental management in the region, subject to its balanced economic development with regard to minimization of environmental damage.

The difference between the expeditionary studies carried out by MHI in 2018 and in 2014-2016 lies in the selection of different schemes for setting up brine sampling stations. In 2018, the selection scheme completely corresponded to the Sivash Bay environmental monitoring system proposed jointly by MHI and SBGOIN [8], which takes into account the current boundaries of "Eastern Sivash" wetland and the most valuable parts of its territory.

The purpose of this study is to analyze the results of MHI expeditionary work in the Sivash Bay water area in the spring and autumn of 2018, to assess the dynamics of salinity, DOM and TSM in the specified water area over the years that have passed after the North Crimean Canal was closed, taking into account the implementation of the ecological monitoring system of the bay. 


\section{Materials and methods}

During field expeditions to the Sivash Bay area, at each of the planned stations water samples for subsequent laboratory measurements of salinity, total suspended $\left(C_{\mathrm{TSM}}\right)$ and dissolved organic $\left(C_{\mathrm{DOM}}\right)$ matter were taken. Water temperature measurements were carried out in situ with a mercury thermometer. The salinity (S) in the sample was determined using a REF 203/213 refractometer. For its calibration a bidistilled water that meets the water quality of DSTU ISO 3696 (class 2, electrical conductivity $0.1 \mathrm{mSm}$ ) was used. Standard normal water (IAPSO standart sea water, batch P152), practical salinity 34,993 \%o was used. The samples of brines, the salinity of which was measured by the pycnometric method, can be used as substandards (when calibrating a refractometer as a field method). All the obtained data were monitored ashore using the pycnometric method. The technique is described in detail in [9].

The spectrometer of directional light attenuation index (transparency meter) at $660 \mathrm{~nm}$ and the fluorimetric meter of dissolved organic matter (fDOM) concentration included into "Kondor" measuring complex* (the main characteristics of the complex are presented in Table 1 and in the works $[10,11]$ ) were applied to determine $C_{\text {TSM }}$ and $C_{\text {DOM }}$. In cases where the values of measured parameters exceeded the sensitivity range of the complex, water samples were diluted with freshly prepared bidistilled water in the required proportions.

T a ble 1

\section{Basic technical characteristics of the complex "Kondor"*}

\begin{tabular}{l|c|c}
\hline \multicolumn{1}{c|}{ Measured characteristics } & $\begin{array}{c}\text { Range of } \\
\text { measurements }\end{array}$ & $\begin{array}{c}\text { Value of the lowest digit } \\
\text { unit, not more than }\end{array}$ \\
\hline Depth, m & $0-100$ & 0.1 \\
Temperature, ${ }^{\circ} \mathrm{C}$ & $-2-32$ & 0.001 \\
Conductivity, mS/cm & $0-69$ & 0.0105 \\
$C_{\text {DOM, }} \mathrm{mg} / \mathrm{l}$ & $0.1-10$ & 0.05 \\
Turbidity, FTU & $0.1-20$ & 0.05 \\
\hline
\end{tabular}

As a result of the expeditionary work execution, a methodology for the rapid assessment of the Sivash Bay water salinity was developed using "Kondor" biophysical sounding complex and REF 203/213 refractometer.

\section{Weather conditions during the expeditions in spring and winter of 2018}

A survey on May 14-15, 2018. During the spring studies, a weak southern wind with a velocity that did not exceed $3 \mathrm{~m} / \mathrm{s}$ was observed. Air temperature on May 14 varied within $17-21^{\circ} \mathrm{C}$ range; on May 15 average daily temperature was by $2{ }^{\circ} \mathrm{C}$ higher. The range of water temperature variability in the Sivash Bay had rather wide limits, $19.5-26^{\circ} \mathrm{C}$. The most uniform temperature distribution $\left(\sim 1.5^{\circ} \mathrm{C}\right)$ was noted at the stations located in the Arabat Spit region, the coldest water was also recorded here. The next day, from noon and until evening, the water temperature

* Hydrooptics ltd. 2020. Hydrobiophysical multiparameter submersible autonomous complex “CONDOR”. [online] Available at: http://ecodevice.com.ru/ecodevice-catalogue/multiturbidimeterkondor [Accessed: 30 September 2019]. 
began to increase from station to station which is most likely due to the daily heating of the bay waters.

A survey on November 7-9, 2018. In late autumn, in the Sivash Bay area air temperature did not exceed $15^{\circ} \mathrm{C}$ during the day and dropped to $7{ }^{\circ} \mathrm{C}$ at night. On the days of the research, a weak wind (up to $3 \mathrm{~m} / \mathrm{s}$ ) of the north-western direction prevailed. The maximum water temperature in the bay was $14{ }^{\circ} \mathrm{C}$, the minimum one $-10^{\circ} \mathrm{C}$.

\section{Results and discussion}

The scheme of sampling stations in the Sivash Bay in May and November 2018 is given in Fig. 1, the results of salinity measuring are shown in Fig. 2 and in Table 2. As follows from the data from Table 2, the salinity continued to increase at the same stations over different seasons, especially in the Southern Sivash (stations 1-8). The difference in salinity values according to two surveys was $14-20 \%$. At all stations located in the Southern Sivash, the salinity varied between 75-82 \% in May, in November - between 91-93\%. The salinity increase declined from south to the north. At stations 11-13, which are the closest to the Tonkiy Strait, the salinity concentration was two times lower than in the Southern Sivash. The salinity at these stations in May was 39, 36, $30 \%$ o, in November - 42, 39, $32 \%$, respectively. Thus, the increase in salinity of the Eastern and Southern Sivash waters continues with a gradual approach to the natural mineralization of the bay, which existed before the launch of the North Crimean Canal. According to expeditionary research performed by MHI, in July 2016 high salinity values, > 73\%, in the Southern Sivash were also noted [7].

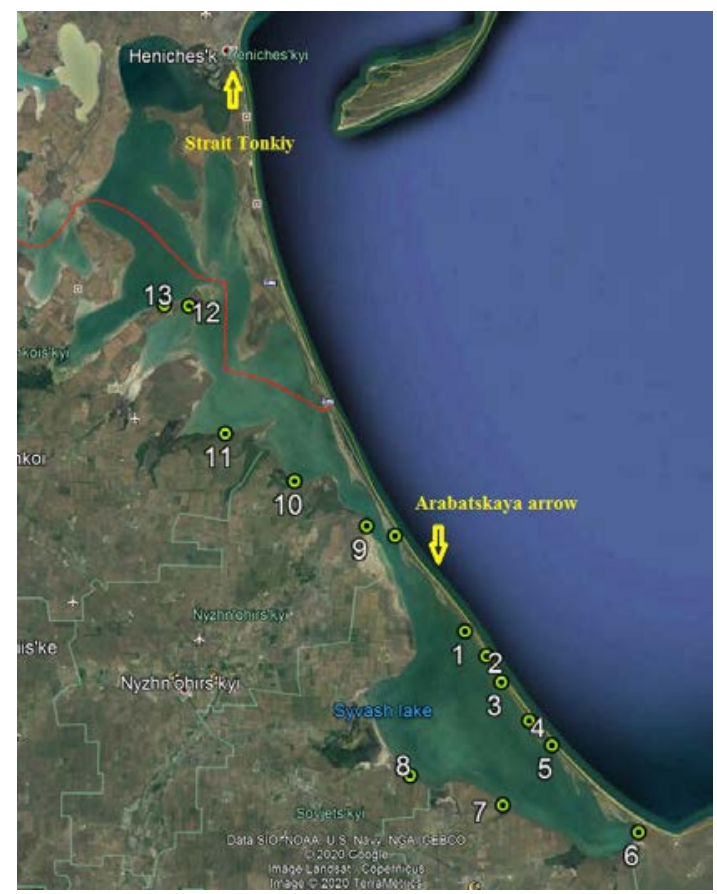

F i g. 1. Scheme of the stations performed by Marine Hydrophysical Institute during the expeditionary studies in 2018 (red line denotes the Russian-Ukrainian boundary) 
In addition to salinity and temperature measurements in the field conditions, the determination of TSM and DOM was carried out. The results on the distribution of these characteristics in the Sivash Bay waters in May and November 2018 are shown in Fig. 3, 4 and Table 2.

In spring, $C_{\text {TSM }}$ values in the studied water area were $2.3-25 \mathrm{mg} / \mathrm{l}$. In TSM spatial distribution some features were observed. Thus, high TSM content (12-24 mg/l) was recorded at the stations located along the Arabat Spit (stations 1-6) and in the area of the Southern Sivash (stations 7, 8). The most transparent water with a minimum content of organic matter was concentrated along the western coast of the Eastern Sivash.

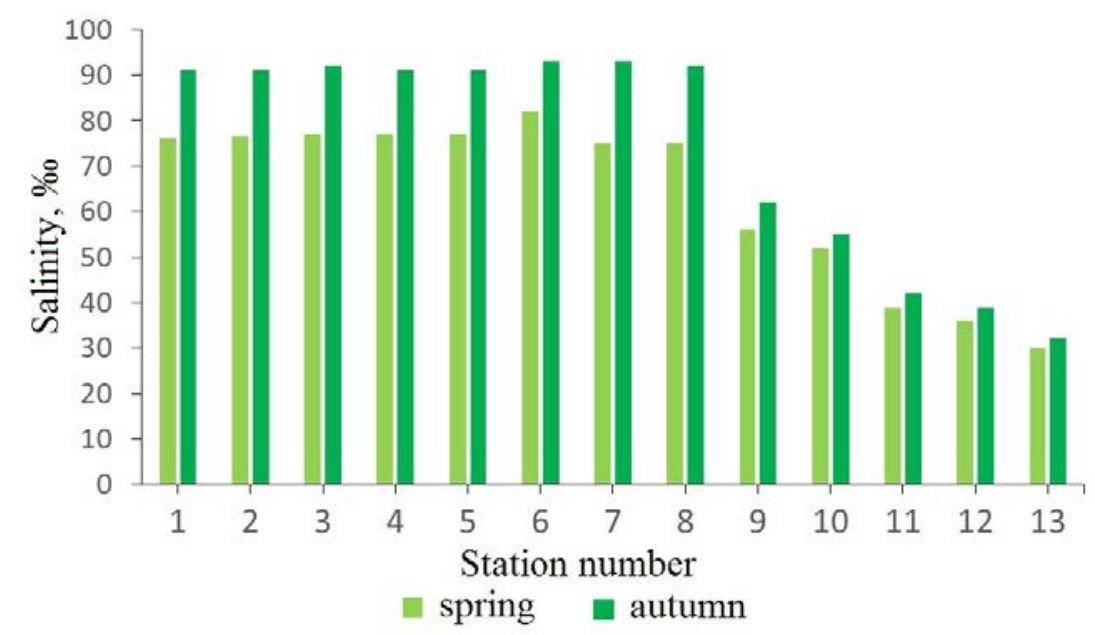

F i g. 2. Salinity variability in the Sivash Bay based on the expeditionary data obtained by Marine Hydrophysical Institute in 2018

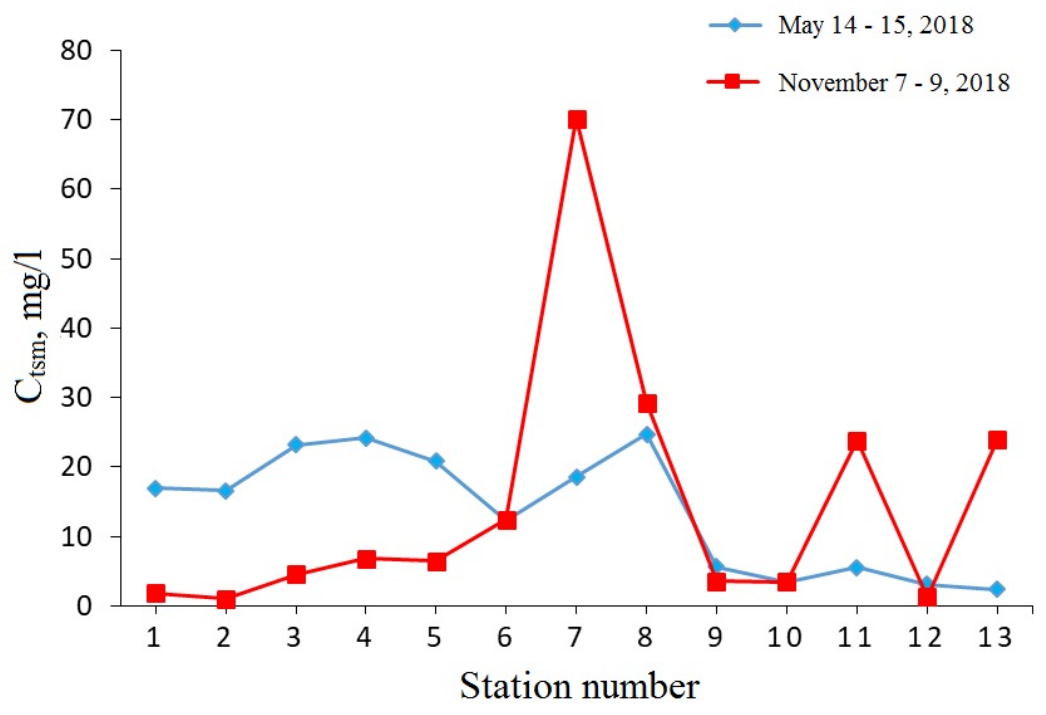

F i g. 3. $C_{\text {TSM }}$ distribution in spring and autumn, 2018 


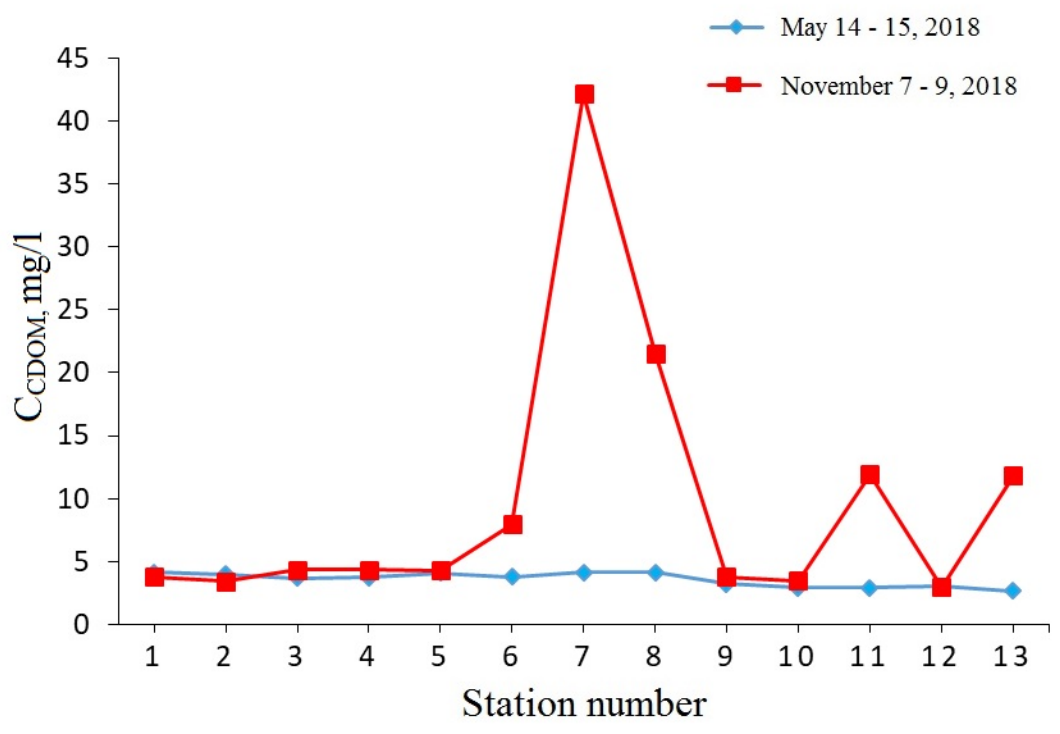

F i g. 4. $C_{\text {Dom }}$ distribution in spring and autumn, 2018

Table 2

Results of the expeditionary studies in the Sivash Bay in May and November, 2018

\begin{tabular}{|c|c|c|c|c|c|c|c|c|}
\hline $\begin{array}{l}\text { Station } \\
\text { number }\end{array}$ & $T,{ }^{\circ} \mathrm{C}$ & $S$, \%о & $\mathrm{TSM}, \mathrm{mg} / \mathrm{l}$ & DOM, mg/l & $T,{ }^{\circ} \mathrm{C}$ & $S, \%$ & TSM, mg/l & DOM, mg/l \\
\hline \multicolumn{5}{|c|}{ May 14-15, 2018} & \multicolumn{4}{|c|}{ November 7-9, 2018} \\
\hline 1 & 21.0 & 76.0 & 16.95 & 4.16 & 12 & 91 & 1.88 & 3.76 \\
\hline 2 & 20.0 & 76.5 & 16.59 & 3.97 & 12 & 91 & 1.03 & 3.44 \\
\hline 3 & 20.0 & 77.0 & 23.15 & 3.68 & 10 & 92 & 4.56 & 4.36 \\
\hline 4 & 20.0 & 77.0 & 24.20 & 3.73 & 11 & 91 & 6.85 & 4.35 \\
\hline 5 & 20.0 & 77.0 & 20.81 & 4.09 & 13 & 91 & 6.47 & 4.31 \\
\hline 6 & 19.5 & 82.0 & 12.20 & 3.80 & 14 & 93 & 12.38 & 7.98 \\
\hline 7 & 21.0 & 75.0 & 18.56 & 4.12 & 13 & 93 & 70.16 & 42.14 \\
\hline 8 & 20.0 & 75.0 & 24.76 & 4.13 & 14 & 92 & 29.27 & 21.56 \\
\hline 9 & 23.0 & 56.0 & 5.64 & 3.21 & 10 & 62 & 3.55 & 3.76 \\
\hline 10 & 24.5 & 52.0 & 3.50 & 2.93 & 10 & 55 & 3.44 & 3.47 \\
\hline 11 & 26.0 & 39.0 & 5.53 & 2.90 & 11 & 42 & 23.83 & 11.92 \\
\hline 12 & 25.0 & 36.0 & 3.11 & 3.01 & 13 & 39 & 1.31 & 2.97 \\
\hline 13 & 23.0 & 30.0 & 2.37 & 2.66 & 12 & 32 & 24.02 & 11.84 \\
\hline
\end{tabular}


In the autumn period TSM variability range was quite wide, $1.8-70 \mathrm{mg} / \mathrm{l}$. The most stable TSM distribution was observed at stations 1-5 located along the Arabat Spit. Unlike the spring period, minimal concentrations of TSM with a tendency of a slight increase in the direction from the north to south were observed here. The maximum concentrations of TSM were recorded in the Southern Sivash (stations 6-8) with a maximum of $70 \mathrm{mg} / \mathrm{l}$ at station 7. The area of the Eastern Sivash western coast was characterized by instability in the TSM content, which was manifested in the alternation of high and low values (Fig. 3).

The weakest variability in the DOM distribution was recorded in spring; its range was $2.7-4.2 \mathrm{mg} / \mathrm{l}$. Despite this, we observed a tendency toward a decrease in the DOM content near the Eastern Sivash western coast compared with the DOM content at stations located along the Arabat Spit.

In the autumn period, the DOM and TSM distribution is similar; $C_{\mathrm{DOM}}$ variability range was $4.4-42 \mathrm{mg} / \mathrm{l}$. The maximum DOM content, $42 \mathrm{mg} / \mathrm{l}$, was also recorded at station 7 (Fig. 4).

Thus, only during the autumn survey an increased content of both TSM and DOM was observed, moreover, it was observed at the same stations (stations 7, 8). In spring, at a monotonous DOM distribution at all stations regardless of the sampling place, the amount of organic matter varied within $2.7-4.0 \mathrm{mg} / \mathrm{l}$. The causes for this distribution are not yet clear. A characteristic dependence was noted for the TSM distribution: in comparison with the data obtained in May, in November a significant increase in $C_{\text {TSM }}$ at station 7 and 8 (70.16 and $\left.29.27 \mathrm{mg} / \mathrm{l}\right)$ was recorded. At these stations, elevated $C_{\text {DOM }}$ values were also determined in November (42.14 and 21.56 $\mathrm{mg} / \mathrm{l})$. The salinity at these stations during this period was $93 \%$ o.

The increased TSM content in autumn 2014 and 2015, noted in [12], is attributed by the authors to the mass death of various species, for example, bivalves, due to a sharp increase in salinity. The destruction of this dead organics could also cause a significant increase in $C_{\text {DOM. }}$.

When studying the causes for the distribution of reed vegetation along the Sivash Bay shores [13], it was shown that its development is directly related to the functioning of the North Crimean Canal and the removal of nutrients by its drainage waters. According to [14], after the canal was blocked, a tendency toward a decrease in the area of reed vegetation tales place. The same pattern was noted visually in the expeditions of Marine Hydrophysical Institute in 2018.

\section{Conclusion}

1. The blocking of the North Crimean Canal in 2014 led to a gradual salinity increase in the water area of the Sivash Bay. Its distribution in different parts of the bay was heterogeneous. As the expeditionary studies of Marine Hydrophysical Institute showed, the highest salinity values were observed in the Southern Sivash: 92-93 \%o in 2018, 55-60 \% in 2016. 
2. When assessing the seasonal dynamics of TSM and DOM content, their high concentrations were recorded during the autumn survey in the bay. In spring, at more monotonous DOM distribution, for TSM an insignificant concentration increase at the stations located in the Southern Sivash was observed.

3. According to the research carried out by Marine Hydrophysical Institute in 2018, the salinity variation in the Sivash Bay is currently ongoing and the ecosystem of the bay is still changing. This requires constant expeditionary observations and the introduction of a modern environmental monitoring system proposed by MHI jointly with SBGOIN.

\section{REFERENCES}

1. Sovga, E.E., Eryemina, E.S. and Khmara, T.V., 2018. Water Balance in the Sivash Bay as a Result of Variability of the Natural-Climatic and Anthropogenic Factors. Physical Oceanography, 25(1), pp. 67-76. doi:10.22449/1573-160X-2018-1-67-76

2. Boltachev, A.R., Karpova, E.P. and Saksaganskii, V.V., 2011. [Transformation of Ichthyocene of East Sivash (Sea of Azov) Effected by Anthropogenic Factors]. In: V.O. Ivanitsa, 2011. Modern Problems of Theoretical and Practical Ichthyology: Proceedings of the $4^{\text {th }}$ International Science Practical Conference (Odessa, 7-11 September 2100). Odessa: Fenix, pp. 40-43.

3. Kostyushin, V.A. and Gorodiskaya, G.A., eds., 2000. The Current Status of Sivash (as a Wetlands). Kiev: Wetlands International-AEME, 104 p. (in Russian).

4. Kostyushina, V.A. and Fesenko, G.V., eds., 2007. Sivash Region: a brief socioeconomic overview. Kiev: Wetlands International Black Sea Progr., 178 p. (in Russian).

5. Marushevsky, G.B., Kostyushin, V.A. and Siohin, V.D., 2005. The Sivash: Nature and People. Kiev: The Black Sea program Wetlands International, $80 \mathrm{p}$. (in Russian).

6. Sovga, E.E. and Shchurova, E.S., 2013. [Resource Potential of the Sivash Bay and Current Ecological State of its Water Area]. In: MHI, 2013. Ekologicheskaya Bezopasnost' Pribrezhnoj iShel'fovoj Zon i Kompleksnoe Ispol'zovanie Resursov Shel'fa [Ecological Safety of Coastal and Shelf Zones and Comprehensive Use of Shelf Resources]. Sevastopol: MHI. Iss. 27, pp. 276-284 (in Russian).

7. Pozachenyuk, E.A., Sovga, E.E., Khmara, T.V., Kharitonova, L.V. and Schurova, E.S., 2016. Methods of Assessment of the Sivash Lagoon State under the North Crimean Canal Overlap in 2014. In: MHI, 2016. Ekologicheskaya Bezopasnost' Pribrezhnoj i Shel'fovoj Zon i Kompleksnoe Ispol'zovanie Resursov Shel'fa [Ecological Safety of Coastal and Shelf Zones and Comprehensive Use of Shelf Resources]. Sevastopol: MHI. Iss. 4, pp. 41-49 (in Russian).

8. Sovga, E.E., Eremina, E.E. and D'yakov, N.N., 2018. System of the Ecological Monitoring in the Sivash Bay in the Modern Conditions. Ecological Safety of Coastal and Shelf Zones of the Sea, (2), pp. 22-38. doi:10.22449/24135577-2018-2-22-38 (in Russian).

9. Sovga, E.E., Lomakin, P.D., Shchurova, E.S. and Ovsyanuy, E.I., 2014. [MHI Expeditionary Research in East Sivash in the Summer and Fall of 2014]. 
In: MHI, 2014. Ekologicheskaya Bezopasnost' Pribrezhnoj i Shel'fovoj Zon I Kompleksnoe Ispol'zovanie Resursov Shel'fa [Ecological Safety of Coastal and Shelf Zones and Comprehensive Use of Shelf Resources]. Sevastopol: MHI. Iss. 28, pp. 138-145 (in Russian).

10. Chepyzhenko, A.I. and Chepyzhenko, A.A., 2017. Methods and Device for In Situ Dissolved Organic Matter (DOM) Monitoring in Natural Waters' Environment. In: SPIE, 2017. Proceedings Volume 10466, 23rd International Symposium on Atmospheric and Ocean Optics: Atmospheric Physic; $104663 \mathrm{~S}$. http://dx.doi.org/10.1117/12.2287797

11. Chepyzhenko, A.A. and Chepyzhenko, A.I., 2017. Methods and Device for in Situ Total Suspended Matter (TSM) Monitoring in Natural Waters' Environment. In: SPIE, 2017. Proceedings Volume 10466, 23rd International Symposium on Atmospheric and Ocean Optics: Atmospheric Physics, $104663 \mathrm{G}$. http://dx.doi.org/10.1117/12.2287127

12. Shadrin, N.V., Sergeeva, N.G., Latushkin, A.A., Kolesnikova, E.A., Kipriyanova, L.M., Anufriieva, E.V. and Chepyzhenko, A.A., 2016. Transformation of Gulf Sivash (the Sea of Azov) in Conditions of Growing Salinity: Changes of Meiobenthos and Other Ecosystem Components (2013-2015). Journal of Siberian Federal University: Biology, 9(4), pp. 452-466. doi:10.17516/1997-1389-2016-9-4452-466 (in Russian).

13. Gromov, V.V., 2012. Aquatic and Coastal Vegetation of the Northern and Western Coast of the Azov Sea. Journal of Siberian Federal University: Biology, 5(2), pp. 121-137. Available at: http://elib.sfu-kras.ru/handle/2311/3076 [Accessed: 20 April 2020] (in Russian).

14. Mikhailov, V., 2019. Development and Dynamics of Coastal Accumulative Forms of Sivash Bay. Geopolitics and Ecogeodynamics of Regions, 5(4), pp. 288-297 (in Russian).

About the authors:

Elena E. Sovga, Leading Research Associate, Marine Hydrophysical Institute of RAS (2 Kapitanskaya St., Sevastopol, 299011, Russian Federation), Dr. Sci. (Geogr.), SPIN-code: 8675-2443, ResearcherID: A-9774-2018, esovga@mhi-ras.ru

Ekaterina S. Eremina, Junior Research Associate, Marine Hydrophysical Institute of RAS (2 Kapitanskaya St., Sevastopol, 299011, Russian Federation), SPIN-code: 5891-9884, ORCID ID: 0000-0002-5596-2691, ResearcherID: E-8676-2018, shchurova88@gmail.com

Aleksandr A. Latushkin, Junior Research Associate, Marine Hydrophysical Institute of RAS (2 Kapitanskaya St., Sevastopol, 299011, Russian Federation), SPIN-code: 1239-2858, sevsalat@gmail.com

Contribution of the co-authors:

Elena E. Sovga - scientific supervision of the research, setting out the objectives and tasks of the research; the processing and description of the results of the study, participation 
in the discussion of the article materials, formulation of the conclusions, preparation of annotation text, critical analysis and revision of the text, preparation of the article text

Ekaterina S. Eremina - analysis of the materials on the research theme, literature review in the research problem, construction of graphs and diagrams, data collection, qualitative and quantitative analysis of the results, participation in the discussion of the article materials

Aleksandr A. Latushkin - development of methods and experimental studies; data collection; qualitative and quantitative analysis of the results; processing and description of the results of the study; preparation of the initial version of the text; building tables, graphs, charts

The authors have read and approved the final manuscript. The authors declare that they have no conflict of interest. 